\title{
The Origin of Quartz Cement in the Upper Triassic Second Member of the Xujiahe Formation Sandstones, Western Sichuan Basin, China
}

\author{
Jie Ren ${ }^{1,2}$, Zhengxiang $\mathrm{Lv}^{1, *}$, Honghui Wang ${ }^{1,3}$, Jianmeng $\mathrm{Wu}^{2}$ and Shunli Zhang ${ }^{4}$ \\ 1 College of Energy Resources, Chengdu University of Technology, Chengdu 610059, China; \\ rj2018cdut@163.com (J.R.); wanghh202013@163.com (H.W.) \\ 2 Sinopec Matrix Xinan MWD/LWD \& Logging Corporation, Chengdu 610100, China; \\ wujm.osxn@sinopec.com \\ 3 Sichuan University of Science \& Engineering, Zigong 643000, China \\ 4 Exploration and Development Research Institute, Sinopec Southwest Company, Chengdu 610041, China; \\ zhangshunli91@163.com \\ * Correspondence: lvzhengxiang13@cdut.cn
}

check for updates

Citation: Ren, J.; Lv, Z.; Wang, H.; Wu, J.; Zhang, S. The Origin of Quartz Cement in the Upper Triassic Second Member of the Xujiahe Formation Sandstones, Western Sichuan Basin, China. Water 2021, 13, 1890. https:// doi.org/10.3390/w13141890

Academic Editor: Howri Mansurbeg

Received: 14 May 2021

Accepted: 3 July 2021

Published: 8 July 2021

Publisher's Note: MDPI stays neutral with regard to jurisdictional claims in published maps and institutional affiliations.

Copyright: (c) 2021 by the authors. Licensee MDPI, Basel, Switzerland. This article is an open access article distributed under the terms and conditions of the Creative Commons Attribution (CC BY) license (https:// creativecommons.org/licenses/by/ $4.0 /)$.

\begin{abstract}
High-precision in situ $\delta^{18} \mathrm{O}$ values obtained using secondary ion mass spectrometry (SIMS) for $\mu \mathrm{m}$-size quartz cement are applied to constrain the origin of the silica in the deep-buried Upper Triassic second member of Xujiahe Formation tight sandstones, western Sichuan Basin, China. Petrographic, cathodoluminescence (CL), and fluid inclusion data from the quartz cements in the Xu2 sandstones indicate three distinct, separate quartz precipitation phases (referred to as Q1, Q2, and Q3). The Q1 quartz cement was formed at temperatures of approximately $56-85^{\circ} \mathrm{C}$ and attained the highest $\delta^{18} \mathrm{O}$ values (ranging from 18.3 to $19.05 \%$ Vienna Standard Mean Ocean Water (VSMOW)). The Q2 quartz cement was generated at temperatures of approximately $90-125^{\circ} \mathrm{C}$, accompanying the main phase of hydrocarbon fluid inclusions, with the highest $\mathrm{Al}_{2} \mathrm{O}_{3}$ content and high $\delta^{18} \mathrm{O}$ values (ranging from 15 to $17.99 \%$ VSMOW). The Q3 quartz cement was formed at temperatures of approximately $130-175{ }^{\circ} \mathrm{C}$, with the lowest $\delta^{18} \mathrm{O}$ values (ranging from 12.79 to $15.47 \%$ vSMOW). A portion of the Q2 and Q3 quartz cement has a relatively high $\mathrm{K}_{2} \mathrm{O}$ content. The dissolution of feldspar and volcanic rock fragments was likely the most important source of silica for the Q1 quartz cement. The variations in $\delta^{18} \mathrm{O}_{\text {(water) }}$ and trace element composition from the Q2 quartz cement to the Q3 quartz cement suggest that hydrocarbon emplacement and water-rock interactions greatly altered the chemistry of the pore fluid. Feldspar dissolution by organic acids, clay mineral reactions (illitization and chloritization of smectite), and pressure dissolution were the main sources of silica for the Q2 and Q3 quartz cements, while transformation of the clay minerals in the external shale unit was a limited silica source.
\end{abstract}

Keywords: quartz cement; oxygen isotopes; silica sources; tight sandstones; Sichuan Basin

\section{Introduction}

Quartz cement is the volumetrically most significant diagenetic mineral altering porosity in deep-buried sandstones, which occurs in mature, medium- to coarse-grained quartz arenites, typical of tectonically stable cratonic basins [1-3]. Understanding the origin and distribution of quartz cement is consequently of economic importance for reservoir quality prediction in oilfield sandstones [4]. Although authigenic quartz cements have been extensively studied, the $\mathrm{pH}$, temperature, pressure, detrital composition, oil and gas emplacement, and chlorite coating play an important role in the precipitation of authigenic quartz, but the formation mechanism and accurate formation time of authigenic quartz are not fully understood [3,5-7]. A certain volume of silica is potentially liberated from pressure solution at grain contacts and through feldspar dissolution, the transformation of smectite into illite or the recrystallization of biogenic silica. Silica solutions are also introduced into 
sand bodies from external sources through faults and fractures or by advection from deep underlying reservoirs or from adjacent shale units [3,7-10]. The quartz cements in most sedimentary basins were formed at diagenetic temperatures ranging from $60-145^{\circ} \mathrm{C}$, at burial depths greater than $2 \mathrm{~km}$, and some scholars have hypothesized that temperaturecontrolled precipitation kinetics are the main control on quartz cement formation and that quartz precipitation exponentially increases with the temperature once the kinetic barriers are overcome above the cement threshold $\left(70-80^{\circ} \mathrm{C}\right)[2,5,11-13]$.

Quartz cement is most abundant in the deep-buried Upper Triassic second member of the Xujiahe Formation tight gas sandstones. Many studies have thus attempted to evaluate the temperature and timing of precipitation as well as the silica origin, typically through the combined application of quartz fluid inclusion and isotopic analysis methods $[9,10,14,15]$. When the temperature of authigenic quartz precipitation is known, the oxygen isotope composition of the fluid from which silica was precipitated can be calculated from the measured oxygen isotope ratios of the quartz cement [16]. In this study, we perform high-precision, high-spatial-resolution secondary ion mass spectrometry (SIMS) analysis of the quartz cement in the second member of the Xujiahe Formation sandstones. With an ion microprobe, individual quartz overgrowths and pore filling quartz cement are analyzed in situ at a spatial resolution of $20-30 \mu \mathrm{m}$. The objective of this study is to interpret the origin and transport mechanism of silica in addition to the nature and composition of the fluids that precipitated the quartz cement in the second member of the Xujiahe Formation sandstones.

\section{Geologic Setting}

The Sichuan Basin is a large oil-bearing superimposed basin. The study area is located in front of the Longmenshan Orogenic Belt, which represents the boundary between the western edge of the Yangtze plate and the Songpan-Ganzi fold (Figure 1a,b). The western Sichuan Basin, in which the study area is located (Figure 1c), is tectonically subdivided into the Zitong depression, Xiaoquan-Fenggu structural zone, Dayi-Yazihe-Anxian fault folding zone, Chengdu depression, and Zhixinchang-Luodai structural zone [17-19].
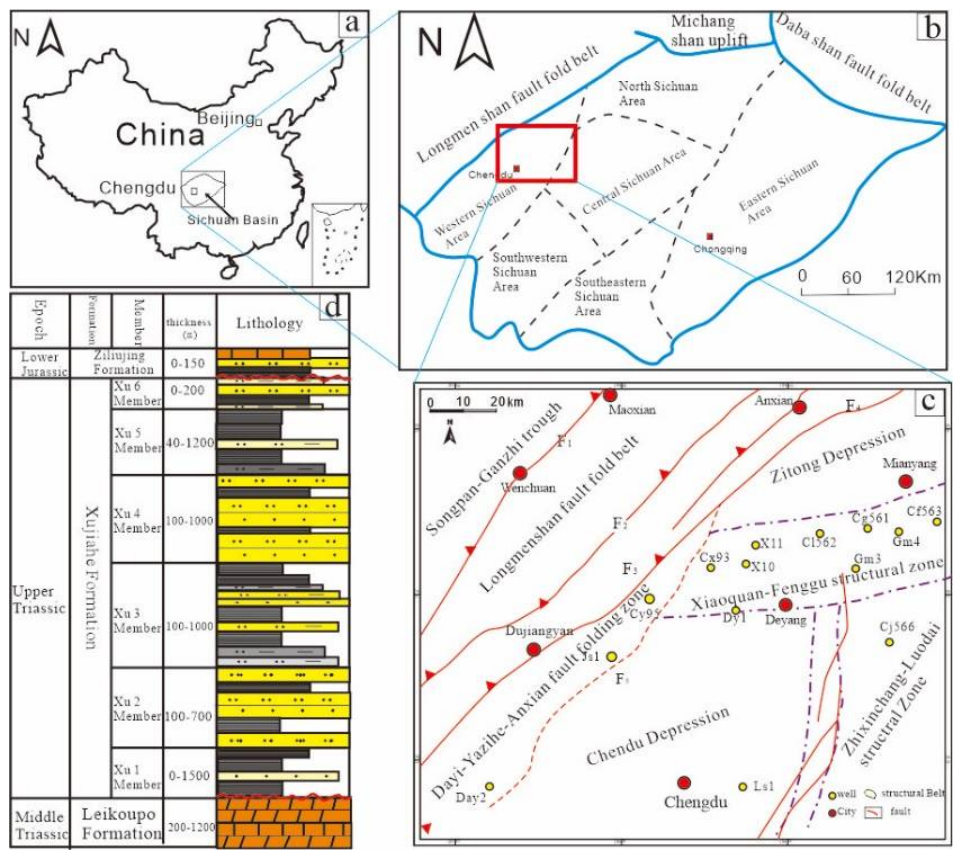

Figure 1. (a) The location of the Sichuan Basin; (b) Geological setting of the Sichuan Basin; (c) The tectonic divisions of the western Sichuan Basin; (d) Generalized stratigraphy and lithological types of the western Sichuan Basin. 
The study area mainly experienced the following two tectonic evolution stages: the SinianMiddle Triassic tectonic evolution of a passive continental margin and the Late Triassic-Eocene evolution of a foreland basin [20,21]. The Indosinian movement at the end of the Late Triassic resulted in the collision of the Yangtze plate with the North China plate. The Longmenshan island chain along the western edge of the Sichuan Basin gradually evolved into a strong thrust nappe orogenic belt and entered the stage of foreland basin evolution, and the coal-bearing clastic rocks of the Xujiahe Formation were deposited [17,18,22-24].

The Xujiahe Formation in the Sichuan Basin unconformably overlies the Middle Triassic Leikoupo Formation, which consists of dolomite, dolomitic limestone, and limestone and is also conformably overlain by the Lower Jurassic Ziliujing Formation. From bottom to top, the Xujiahe Formation in the western Sichuan Basin can be divided into five members, namely, Xu1-Xu5 (Figure 1d). The Xu1, Xu3 and Xu5 members mainly consist of black shale, mudstone, and coal seams and are regional petroleum source rocks for the Xujiahe Formation, whereas the $\mathrm{Xu} 2$ and $\mathrm{Xu} 4$ members are predominantly sandstones, which are an important sandstone reservoir and production layer, respectively, in the western Sichuan Basin $[19,25]$. The burial depth of the $\mathrm{Xu} 2$ member is more than $4600 \mathrm{~m}$, and the sedimentary thickness is between 560 and $660 \mathrm{~m}$. The Xu2 member was largely deposited in a marine delta front belonging to a marine-to-continental transitional environment, mainly consisting of distributary channel and mouth bar sandstones $[19,23,26]$.

\section{Materials and Methods}

A total of 102 samples were collected from 8 wells in the $\mathrm{Xu} 2$ member in the western Sichuan Basin, at burial depths ranging from 4800-5200 m. Eighty-six samples were selected for thin section observation, and thin sections were prepared for multiple purposes via blue-dyed epoxy impregnation and double-sided polishing. The mineral composition was identified using polarized light microscopy, and X-ray diffraction (XRD) analysis was performed on 22 bulk samples and $<2 \mu \mathrm{m}$ size fractions using a Neo-Confucianism DMAX-3C diffractometer. The geochemical and information of the diagenetic minerals was evaluated via cathodoluminescence (CL) analysis. The instrument model is CL8200MK5, and the analysis was performed at an accelerating voltage of $30 \mathrm{kV}$, with a $2 \mathrm{Na}$ beam current and a 5-millimeter working distance.

Fifteen double-sided polished thin sections were selected for microthermometric measurements. The homogenization temperatures were measured using a Linkam THMS-600 heating/cooling stage. Only primary fluid inclusions containing both aqueous and hydrocarbon phases were selected from the authigenic minerals to determine their minimum precipitation temperatures.

The chemical composition of the quartz cements was quantitatively determined using electron microprobe analysis (EMPA) with an EPMA-1720JXA-8100 electron microprobe (operating conditions: $15-\mathrm{kV}$ accelerating voltage, 10-nA current, and 1-micrometer beam diameter) at the State Key Laboratory of Oil and Gas Reservoir Geology and Exploitation in Chengdu. The accuracy of experimental analysis is $-3-+3 \%$. Four thin sections and 24 sample points were analyzed.

Ion microprobe spots were identified using CL and reflected microscopy, and any areas with well-developed quartz cements ( $>25 \mu \mathrm{m}$ wide) were cored from the double-thickness polished thin sections and then packed into one block alongside international NBS-28 standard quartz grains. In situ SIMS oxygen isotopic composition analysis of the detrital quartz and quartz overgrowths was conducted using a CAMECA IMS-1280 ion microprobe with an approximately 15-micrometer diameter beam at the Institute of Geology and Geophysics, Chinese Academy of Sciences (IGGCAS) in Beijing, and the internal precision of $\delta^{18} \mathrm{O}$ was ca. $0.2 \%$ o (2 standard deviations, 2SDs) based on 20 measurement cycles $[27,28]$. 


\section{Results}

\subsection{Petrographic Description}

The sandstone of the $\mathrm{Xu} 2$ member is mainly composed of fine- to medium-grained litharenites, sublitharenites, and feldspathic litharenites (Figure 2). The detrital composition is primarily quartz, and the sandstone is relatively poor in feldspar and rich in rock fragments. The rock fragments are predominantly metamorphic and igneous rock fragments, while the feldspars are largely potassic feldspars (orthoclase and microcline) with small quantities of plagioclase. The main components of the interstitial materials are clay matrix and cements such as quartz, chlorite, illite, and carbonates.

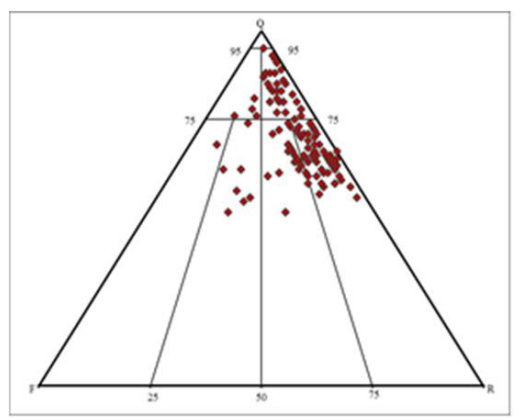

Figure 2. Ternary diagram based on Folk (1968) illustrating the composition of the Xu2 sandstones. Q-detrital quartz grains, F-detrital feldspar grains, R-rock fragments.

\subsection{Diagenesis Types and Characteristics}

The compaction and pressure dissolution degrees of the deep-buried sandstone in the Xu2 member are high. According to the thin section analysis, line, concave convex, and stylolite contacts occur between the detrital grains, while mica or plastic rock fragment were deformed by compaction (Figure 3a).

K-feldspar dissolution commonly produced secondary pores, which highly improves the reservoir quality of tight sandstones, dissolution was enhanced by fractured grains (Figure $3 b, c)$. Feldspar dissolution mainly occurred along the edges and cleavage surfaces of detrital grains. Some feldspar was largely dissolved to form a honeycomb or hole structure, while the chlorite layer previously covering the detrital grains remains (Figure 3d). It can be seen that carbonate minerals are recrystallized with euhedral outlines and filled in feldspar dissolution pores (Figure $3 \mathrm{e}, \mathrm{f}$ ).

According to the XRD analysis and scanning electron microscopy (SEM) observation, the authigenic clay minerals are primarily chlorite and illite, with no kaolinite. Illite is the most common clay mineral, and it generally occurs as fibrous or hairlike crystals in primary pores as well as within the secondary pores in feldspar grains (Figure 3g). Chlorite is also an important clay mineral in tight sandstone reservoirs, and it usually occurs as rosette-shaped and needle crystals on grain surfaces or in primary pores (Figure $3 \mathrm{~h}$ ). 

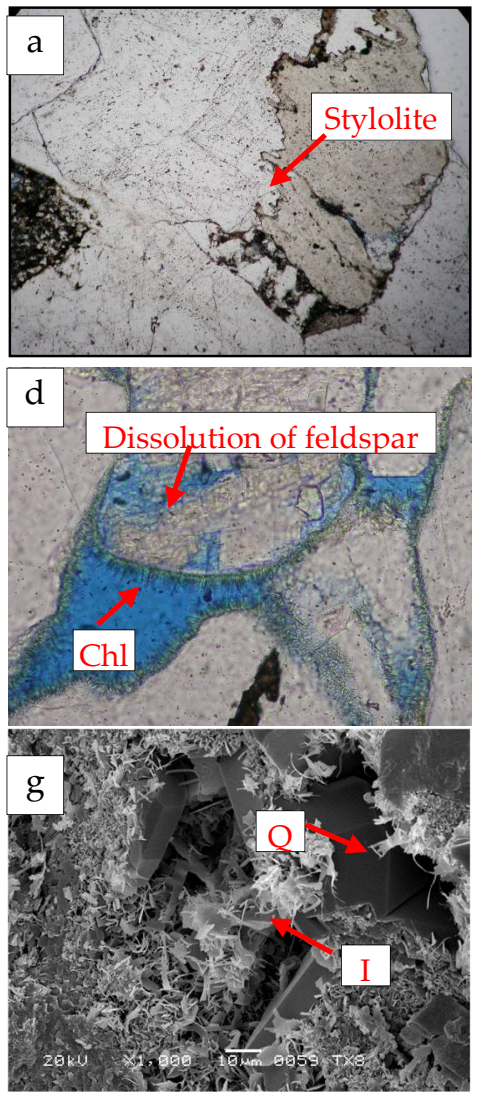
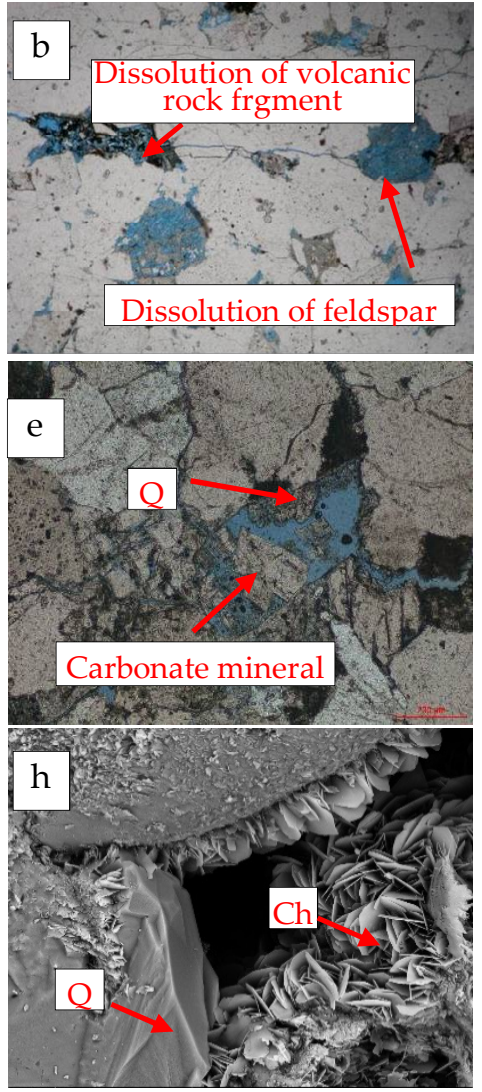
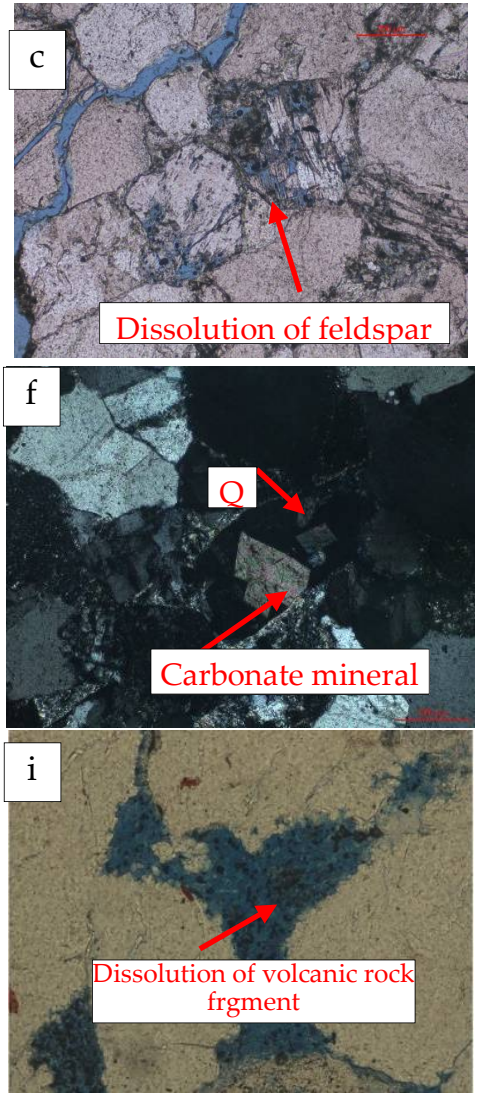

Figure 3. Photomicrographs showing the diagenesis characteristics of the $\mathrm{Xu} 2$ sandstones. (a) Stylolite contact of the quartz detrital grains, CG561 well, 4926.65 m, plane-polarized light (PPL) analysis; (b) Dissolution of feldspar and volcanic rock fragments associated with fractures, intragranular dissolution pores, CX565 well, $4898.31 \mathrm{~m}$, PPL; (c) Dissolution of feldspar associated with fractures, intragranular dissolution pores, ZT1 well, $3667.6 \mathrm{~m}$, PPL; (d) Dissolution of feldspar and chlorite layer, CG561 well, 4992.9 m, PPL; (e) Dissolution of feldspar, carbonate mineral recrystallization, ZT1 well, 3673.05 m, PPL; (f) Dissolution of feldspar, carbonate mineral recrystallization, ZT1 well, 3673.05 m, XPL; (g) Illite and authigenic quartz cements, X10 well, 4880.24 m, SEM; (h) Chlorite-coated and authigenic quartz cements, JH2 well, 3440.42 m, SEM; (i) Dissolution of volcanic rock, CG561 well, $4993.54 \mathrm{~m}$.

Quartz cements are volumetrically significant in more mature sandstones and commonly increase with the burial depth. Quartz cements occupy notable amounts of the pore space ( $7 \%$ on average) in the $\mathrm{Xu} 2$ sandstones. Three quartz cement formation phases can be distinguished based on the thin section and CL analyses, which are referred to as Q1, Q2, and Q3 (Figure 4). The Q1 quartz cement, which is in direct contact with the quartz grains, is characterized by thin overgrowths surrounding detrital quartz grains and exhibits a slightly gray-black luminescence. It was likely formed earlier than the chlorite- coating (Figure 4a). The subsequently formed Q2 quartz cement is characterized by overgrowths, commonly overlying the Q1 overgrowths, and exhibits a slightly gray-black luminescence, The Q2 quartz cement is volumetrically than Q1 quartz cement (Figure $4 \mathrm{~b}-\mathrm{d}$ ). The Q3 quartz cement usually fills intergranular pores and intragranular dissolution pores with euhedral crystals and it exhibits a homogeneous, dark brown luminescence (Figure $4 b-d$ ). 

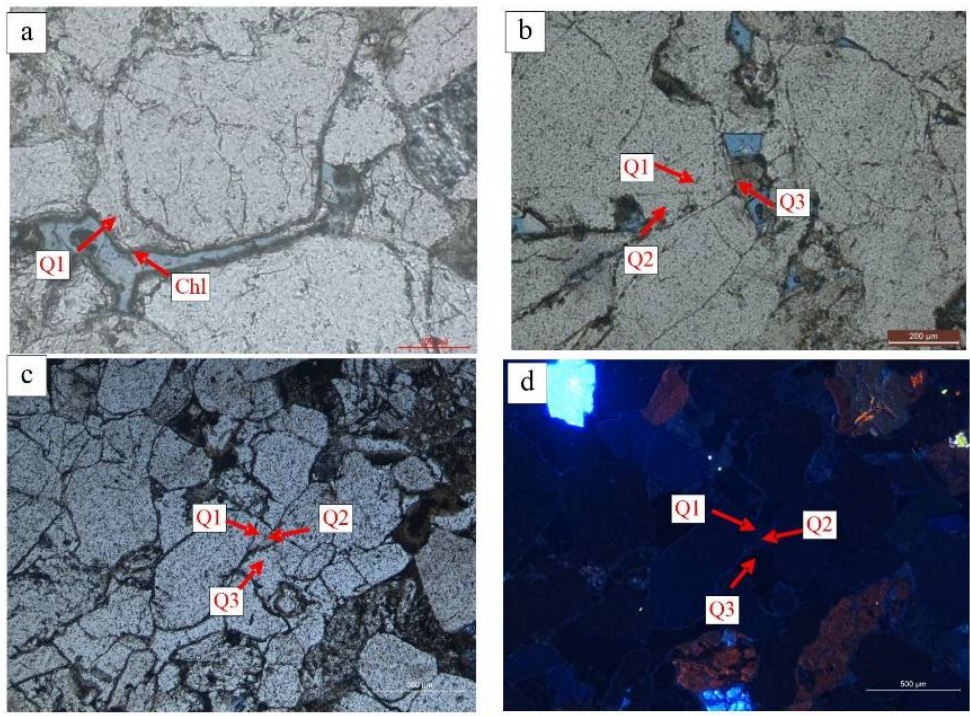

Figure 4. Photomicrographs showing the characteristics of the quartz cements. (a) Q1 quartz cement, which precipitated earlier than the chlorite-coated did, JH2 well, 3419 m, PPL; (b) Three phases of the quartz cements referred to as Q1, Q2, and Q3, X10 well, $4880.54 \mathrm{~m}, \mathrm{PPL}$; (c) Three phases of the quartz cements referred to as Q1, Q2, and Q3, JH2 well, $3440.42 \mathrm{~m}$, PPL; (d) Three phases of the quartz cements referred to as Q1, Q2, and Q3, JH2 well, $3440.42 \mathrm{~m}, \mathrm{CL}$.

\subsection{Fluid Inclusion Analysis of the Quartz Cements}

Fluid inclusion microthermometric data of the quartz cements were acquired for 39 data points. Primary aqueous fluid inclusions commonly occur along the surface (dust rim) separating the detrital grains from the authigenic overgrowths. The data, however, suggest a trimodal distribution, with three distinct temperature intervals of $64-85,95-125$, and $130-170{ }^{\circ} \mathrm{C}$ (Figure 5), corresponding to the Q1, Q2, and Q3 quartz cements, respectively.

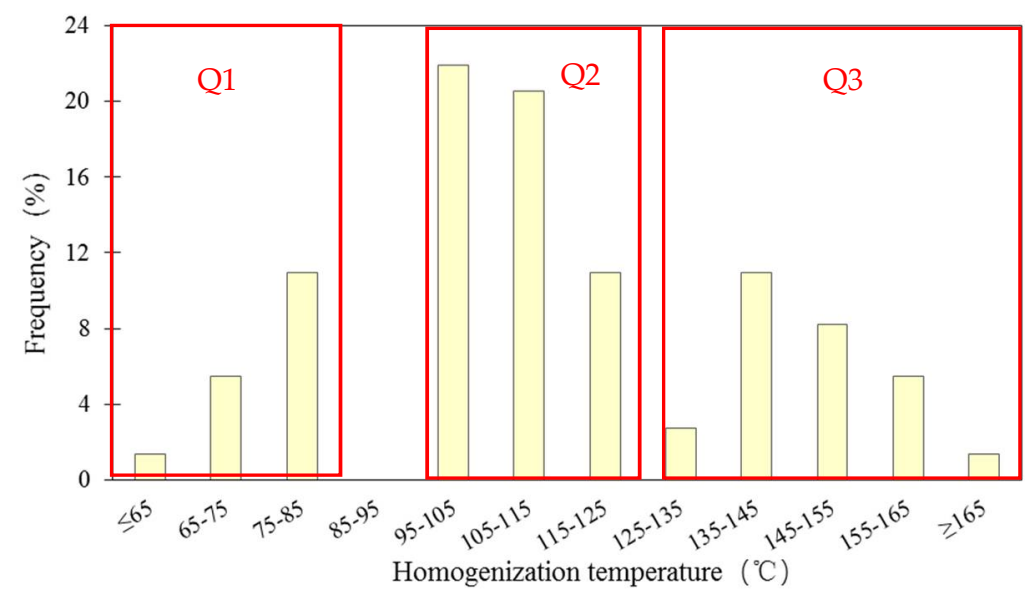

Figure 5. Histograms of the homogenization temperature (Th) in the different phases of the quartz cements in the $\mathrm{Xu} 2$ sandstones.

Hydrocarbon fluid inclusions were mainly found in the Q2 and Q3 quartz cements, which emit blue fluorescence under fluorescence microscopy. Similarly, through analysis of the burial history and temperature, source rock maturation and hydrocarbon migration occurred simultaneously with the growth of the Q2 and Q3 quartz cements [23].

\subsection{The $\delta^{18} O$ Data of the Quartz Cements and Quartz Grains}

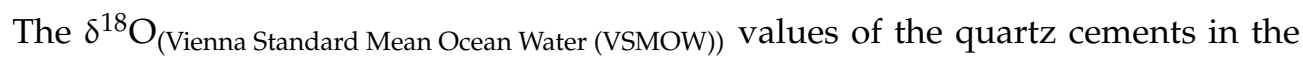
Xu2 sandstones range from 6.56 to $18.91 \%$ o $(n=23)$ (average 14.33\%) and are higher than 
those of the detrital quartz grains, which range from 6.56 to $8.21 \%$ o $(n=7)$. The $\delta^{18} \mathrm{O}_{\text {(VSMOW) }}$ value of the Q1 quartz cement ranges from 18.3 to $19.05 \%$ o $(n=6)$, with an average of $18.61 \%$, and that of the Q2 quartz cement ranges from 15 to $17.99 \%(n=7)$, with an average of $16.76 \%$, while that of the Q3 quartz cement ranges from 12.79 to $15.47 \%$ o $(n=10)$, with an average of $14.22 \%$. These data reveal that the $\delta^{18} \mathrm{O}_{\text {(VSMOW) }}$ value gradually decreases with the distance from the quartz cement to the boundary of the detrital quartz grain (Figure 6, Table 1).

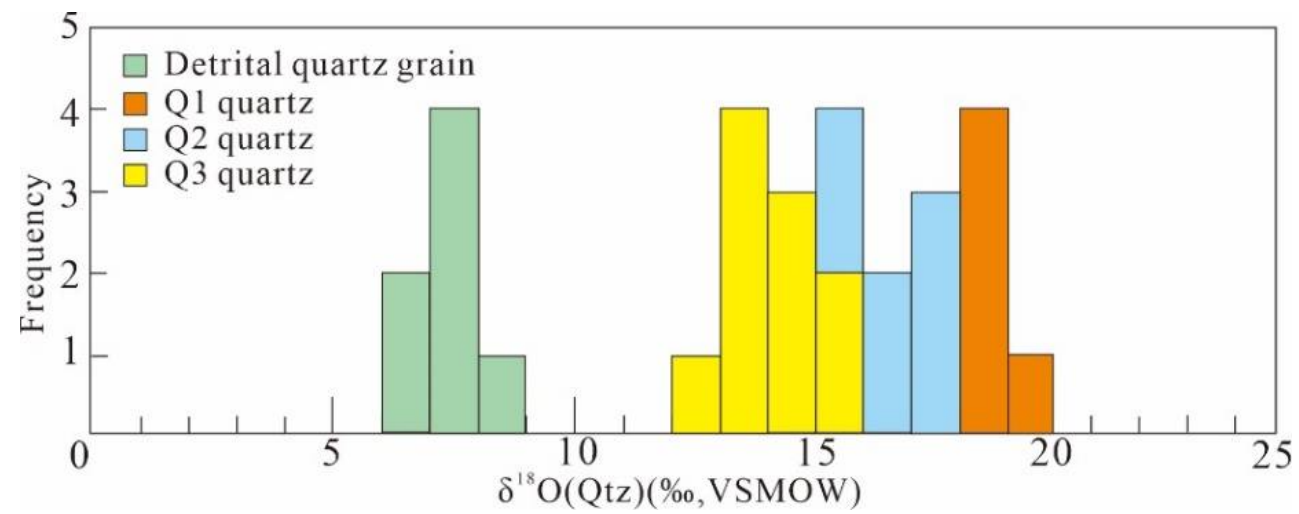

Figure 6. Histograms of the oxygen isotope ratios of the quartz in the $\mathrm{Xu} 2$ sandstones measured in situ, including the cements and detrital quartz grains.

Table 1. Oxygen isotope ratios of the quartz in the Xu2 sandstones measured in situ, including the cements and detrital quartz grains.

\begin{tabular}{|c|c|c|c|c|}
\hline Point & Sample ID & $\delta 180 \%($ SMOW $)$ & $2 \mathrm{SE}$ & $\begin{array}{c}\text { Cements and Detrital } \\
\text { Quartz Grains }\end{array}$ \\
\hline 1 & $44-2$ & 15.35 & 0.13 & Q3 quartz \\
\hline 2 & $44-1$ & 17.99 & 0.18 & Q2 quartz \\
\hline 3 & 44 & 18.56 & 0.22 & Q1 quartz \\
\hline 4 & $44-3$ & 8.21 & 0.18 & Detrital quartz grain \\
\hline 5 & $77-3$ & 12.79 & 0.12 & Q3 quartz \\
\hline 6 & $77-5$ & 17.97 & 0.22 & Q2 quartz \\
\hline 7 & $77-2$ & 18.30 & 0.19 & Q1 quartz \\
\hline 8 & $77-4$ & 7.98 & 0.30 & Detrital quartz grain \\
\hline 9 & $77-1$ & 7.20 & 0.20 & Detrital quartz grain \\
\hline 10 & 77 & 6.76 & 0.22 & Detrital quartz grain \\
\hline 11 & x10-1 & 14.54 & 0.12 & Q3 quartz \\
\hline 12 & $x 10-2$ & 14.84 & 0.20 & Q3 quartz \\
\hline 13 & $x 10-5$ & 15.00 & 0.18 & Q2 quartz \\
\hline 14 & $x 10-4$ & 17.82 & 0.19 & Q2 quartz \\
\hline 15 & $x 10-3$ & 15.99 & 0.18 & Q2 quartz \\
\hline 16 & $x 10-8$ & 18.32 & 0.20 & Q1 quartz \\
\hline 17 & $x 10-9$ & 18.91 & 0.15 & Q1 quartz \\
\hline 18 & $x 10-12$ & 7.77 & 0.18 & Detrital quartz grain \\
\hline 19 & $x 10-10$ & 7.44 & 0.18 & Detrital quartz grain \\
\hline 20 & $x 10-11$ & 6.56 & 0.19 & Detrital quartz grain \\
\hline 21 & $121-2$ & 14.05 & 0.08 & Q3 quartz \\
\hline 22 & $121-3$ & 13.98 & 0.24 & Q3 quartz \\
\hline 23 & $121-4$ & 13.91 & 0.31 & Q3 quartz \\
\hline 24 & 121 & 13.78 & 0.28 & Q3 quartz \\
\hline 25 & $121-7$ & 15.47 & 0.13 & Q3 quartz \\
\hline 26 & $121-6$ & 13.52 & 0.18 & Q3 quartz \\
\hline 27 & $121-8$ & 16.44 & 0.19 & Q2 quartz \\
\hline 28 & $121-9$ & 16.11 & 0.19 & Q2 quartz \\
\hline 29 & $121-10$ & 19.05 & 0.23 & Q1 quartz \\
\hline 30 & $121-11$ & 18.45 & 0.18 & Q1 quartz \\
\hline
\end{tabular}




\subsection{Electron Probe Analysis of the Quartz Cements}

The trace elements in each quartz cement phase were analyzed with the electron microprobe. A summary of the trace element analysis results is shown in Figure 7, and all the data represent the mass fraction percentage. Notably, aluminum exhibits the largest variation across the quartz cement phases. The Q1 quartz cement contains the lowest $\mathrm{Al}_{2} \mathrm{O}_{3}$ content with an average of $0.014 \%$. The most volumetrically important Q2 quartz cement exhibits the highest $\mathrm{Al}_{2} \mathrm{O}_{3}$ content with a mean value of $0.148 \%$. The Q3 quartz is Al-depleted, with a mean value of $0.075 \%$. Moreover, some Q2 and Q3 quartz cements attains a relatively high $\mathrm{K}_{2} \mathrm{O}$ content.

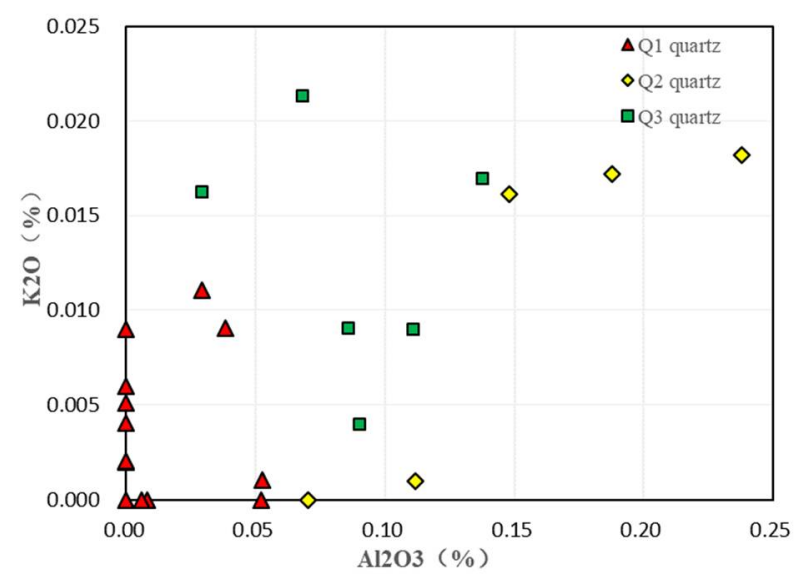

Figure 7. Relationship between $\mathrm{Al}_{2} \mathrm{O}_{3}$ and $\mathrm{K}_{2} \mathrm{O}$ in the different quartz cement phases.

\section{Discussion}

\subsection{Nature and Origin of the Fluid}

The $\delta^{18} \mathrm{O}_{\text {(VSMOW) }}$ values of the quartz cements can be employed to analyze the properties of the diagenetic fluids $[9,14,15,27]$. The quartz-water fractionation equation of Clayton et al. (1972) [29] is as follows:

$$
1000 \ln \alpha_{(\text {quartz-water })}=3.38\left(10^{6} \times \mathrm{T}^{-2}\right)-3.40
$$

The Q1 quartz cement precipitated earlier than the chlorite-coated (Figure 4a), with fluid inclusions exhibiting a homogenization temperature ranging from 64 to $85^{\circ} \mathrm{C}$ and a calculated paleofluid $\delta^{18} \mathrm{O}_{\text {(water) }}$ value ranging from -8.16 to $-4.05 \%$ VSMOW, close to the value of meteoric water $(-7 \%$ ) (Figure 8$)$. The paleofluid may have been influenced by meteoric water. The Q2 quartz cement was mainly formed from 95 to $125^{\circ} \mathrm{C}$, and the calculated paleofluid $\delta^{18} \mathrm{O}_{\text {(water) }}$ value ranges from -6.63 to $-0.09 \%$ VSMOW (Figure 8). Since the oxygen isotope composition of the formation waters generally evolves to more positive values with increasing burial as a result of water-rock reactions, the recrystallization reactions of the clay minerals and hydrocarbon emplacement tend to result in $\delta^{18} \mathrm{O}_{\text {(water) }}$ enhancement [4,30-32], and it is inferred that the pore fluid maybe the complex high-temperature mixed fluid remaining after hydrocarbon emplacement and water-rock reactions. The Q3 quartz cement primarily formed from 130 to $170{ }^{\circ} \mathrm{C}$, and the calculated paleofluid $\delta^{18} \mathrm{O}_{\text {(water) }}$ value ranges from -4.68to 1.54\% VSMOW (Figure 8). According to the thermal and burial histories (Figure 9), the burial depth of this stage reached $3500 \mathrm{~m}$, and the pore water $\delta^{18} \mathrm{O}_{\text {(water) }}$ value continuously increased in the middle and late diagenetic stages due to the release of $\mathrm{SiO}_{2}$ by pressure solution and carbonate mineral recrystallization $[4,10,30,31]$. It is inferred that the pore fluid in this stage is mainly the mixed fluid remaining after pressure dissolution and water-rock reaction interactions. 


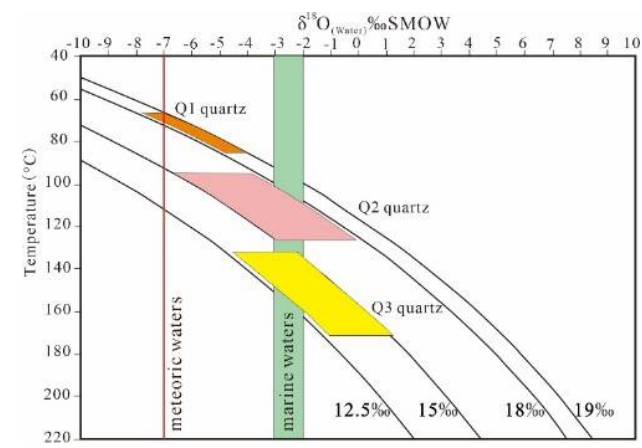

Figure 8. Plot of $\delta^{18} \mathrm{O}_{\text {(water) }}$ in equilibrium with $\delta^{18} \mathrm{O}_{\text {(cement) }}=12.5,15,18$, and $19 \%$ os a function of the temperature [29], Late Triassic marine waters, $\delta^{18} \mathrm{O}_{\text {(water) }}=$ approximately -3 to $-2 \%$ [33,34], and meteoric waters, $\delta^{18} \mathrm{O}_{(\text {water })}=-7 \%$ o $[4,35]$.

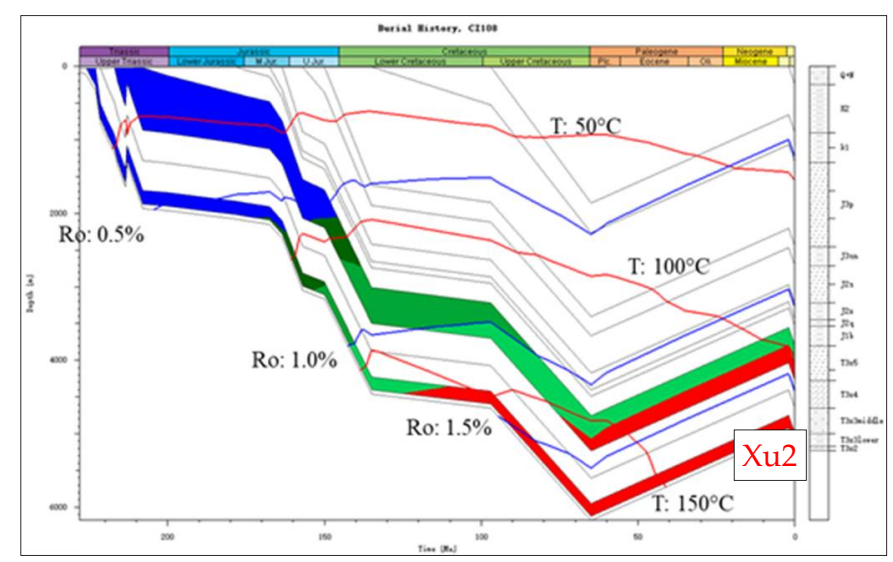

Figure 9. Burial history of the Xu2 member in Western Sichuan Basin.

\subsection{Silica Sources}

The potential sources of silica for quartz cementation in the sandstones can be summarized as biogenic silica, feldspar dissolution, clay mineral transformation, and pressure dissolution of detrital quartz grains [3]. The Q1 quartz cement was mainly formed at a temperature range of 64 to $85^{\circ} \mathrm{C}$, and the isotopic analysis of the Q1 quartz cement reveals a meteoric water influence. Sandstones containing biogenic silica are generally deposited in marine environments, and they could be potential silica sources in the early diagenetic stage, whereas the Xujiahe Formation is a nonmarine deposit. Therefore, biogenic silica is excluded. At low temperatures, meteoric water dissolves volcanic rock fragments and feldspar, thereby releasing silica [27,36-39] (Figure 3b,i). The fraction of silica released from the dissolution of feldspar minerals can reach as high as $0.43 \mathrm{~cm}^{3}$ per $\mathrm{cm}^{3}$ of the dissolved feldspar depending on the original composition and type of the feldspar minerals $[40,41]$. Therefore, it appears that the dissolution of feldspar and volcanic rock fragments may be the most important source of silica for the Q1 quartz cement.

The Q2 quartz cement was primarily formed from 95 to $125^{\circ} \mathrm{C}$. According to its burial history, the organic acids released from the mature organic matter likely created an acidic environment, which facilitated the precipitation of authigenic quartz [5,42]. Moreover, the acidic fluid dissolved feldspar, and the pore water was enriched with $\mathrm{Al}^{3+}, \mathrm{K}^{+}$, and $\mathrm{Na}^{+}$; authigenic quartz generally also contains a small amount of trace elements [3]. EPMA analysis reveals that the $\mathrm{Q} 2$ quartz cement exhibits a relatively high $\mathrm{K}_{2} \mathrm{O}$ content, with the highest $\mathrm{Al}_{2} \mathrm{O}_{3}$ content (Figure 7). The SEM indicates that the authigenic quartz fills the dissolution pores of the feldspar detrital grains (Figure 10). 

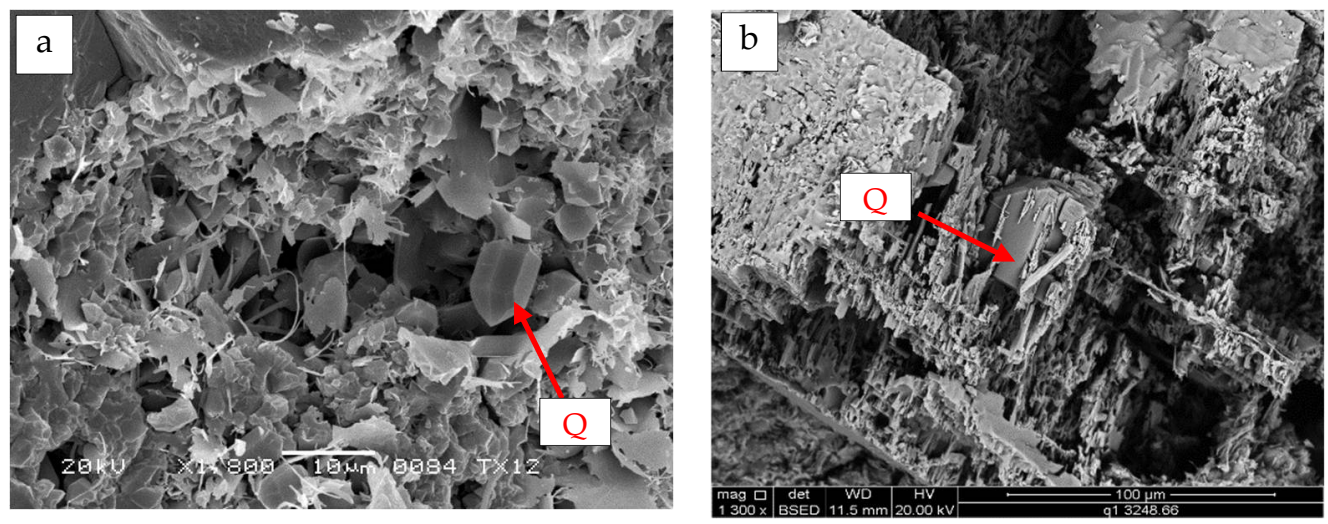

Figure 10. Scanning electron microscopy images showing the characteristics of the quartz cements. (a) Dissolution pores of rock fragments filled with authigenic quartz and illite, X10 well, $4880.54 \mathrm{~m}$; (b) Dissolution pores of feldspar filled with authigenic quartz, ZT1 well, $3673.05 \mathrm{~m}$.

With an increasing temperature, the smectite in sandstones or adjacent mudstones is gradually transformed into illite or chlorite $[3,8,43,44]$. The original composition of the smectite may determine whether it is transformed into illite or chlorite. $\mathrm{Mg}$ Fe-rich smectite tends to be chloritized, whereas $\mathrm{K}-, \mathrm{Ca}-$, and Na-rich smectite tend to be illitized [7,45]. The clay minerals in the $\mathrm{Xu} 2$ sandstone are mainly illite and chlorite and are associated with the authigenic quartz (Figure 3g,h). This demonstrates that the transformation of clay minerals could be a potential silica source, but regarding the silica formed in the external shale unit, there must be a suitable transport mechanism for precipitation in the adjacent sandstone reservoir, which is more difficult for the deep-buried thick sandstone of the second member of the Xujiahe Formation. Therefore, the dissolution of feldspar and the transformation of the clay minerals in the $\mathrm{Xu} 2$ sandstone appear to have been the most important sources of silica for the Q2 quartz cement.

The Q3 quartz cement formation temperature is generally higher than $130{ }^{\circ} \mathrm{C}$, and the burial depth of the $\mathrm{Xu} 2$ sandstone is generally greater than $4500 \mathrm{~m}$. The thin sections reveal that intergranular pressure dissolution and stylolites are common (Figure 3a), indicating that this process could be considered an important source of silica for the Q3 quartz cement. Moreover, mica and illite clay minerals promote quartz grain pressure dissolution to produce free silica $[46,47]$ (Figure 3a). Therefore, pressure dissolution appears to have been the most important source of silica for the Q3 quartz cement.

\section{Conclusions}

1. Three quartz cement phases are identified based on thin section analysis, CL, and fluid inclusion microthermometry, with three distinct temperature intervals of 56-85, $90-125$, and $130-175^{\circ} \mathrm{C}$. Hydrocarbon fluid inclusions are mainly found in the Q2 and Q3 quartz cements, which emit blue fluorescence under fluorescence microscopy.

2. The $\delta^{18} \mathrm{O}$ values of the quartz cements range from 6.56 to $18.91 \%$ o $(n=23)$ (average: $14.33 \%$ ) and are higher than those of the detrital quartz grains. The $\delta^{18} \mathrm{O}_{\text {(VSMOW) }}$ value of the Q1 quartz cement ranges from 18.3 to $19.05 \%$, that of the Q2 quartz cement ranges from 15 to $17.99 \%$, while that of the Q3 quartz cement ranges from 12.79 to $15.47 \%$.

3. The $\mathrm{Q} 1$ quartz cement has the lowest $\mathrm{Al}_{2} \mathrm{O}_{3}$ content with an average of $0.014 \%$. The Q2 quartz cement exhibits the highest $\mathrm{Al}_{2} \mathrm{O}_{3}$ content with a mean value of $0.148 \%$. The Q3 quartz cement is Al-depleted, with a mean value of $0.075 \%$. Moreover, some $\mathrm{Q} 2$ and Q3 quart cements samples achieve a relatively high $\mathrm{K}_{2} \mathrm{O}$ content.

4. The dissolution of feldspar and unstable volcanic rock fragments appears to have been the most important source of silica for the Q1 quartz cement. The variations in $\delta^{18} \mathrm{O}_{\text {(water) }}$ and trace element composition from the Q2 quartz cement to the Q3 quartz cement suggest that hydrocarbon emplacement and water-rock interactions greatly 
altered the chemistry of the pore fluid. The dissolution of feldspar, clay mineral transformation, and pressure dissolution appear to have been the most important sources of silica for the Q2 and Q3 quartz cements. The transformation of the clay minerals in the external shale unit was a limited source of silica.

Author Contributions: Conceptualization, Z.L.; formal Analysis, J.W.; data Curation, J.W.; writingoriginal draft preparation, J.R. and H.W.; writing - review and editing, S.Z. and Z.L. All authors have read and agreed to the published version of the manuscript.

Funding: Our team was supported by the National Science and Technology Major Project [grant number 2016ZX05002-004-010].

Acknowledgments: We thank the anonymous reviewers for their valuable suggestions and kind help in improving the quality of the manuscript, and the Southeast Branch Company of SINOPEC for sample collection and technical support.

Conflicts of Interest: The authors declare no conflict of interest.

\section{References}

1. Houseknecht, D.W. Influence of Grain Size and Thermal Maturity on Intergranular Pressure Solution and Quartz Cementation in a Quartz-Rich Sandstone. J. Sediment. Petrol. 1984, 54, 348-361. [CrossRef]

2. Bjorlykke, K.; Egeberg, P. Quartz Cementation in Sedimentary Basins. AAPG Bull. 1993, 77, 1538-1548.

3. Worden, R.H.; Morad, S. Quartz Cementation in Sandstones; International Association of Sedimentologists, Special Publication, Blackwell Science: Oxford, UK, 2000.

4. Marchand, A.M.E.; Macaulay, C.I.; Haszeldine, R.S.; Fallick, A.E. Pore water evolution in oilfield sandstones: Constraints from oxygen isotope microanalyses of quartz cement. Chem. Geol. 2002, 191, 285-304. [CrossRef]

5. Mcbride, E.F. Quartz cement in sandstones: A review. Earth-Sci. Rev. 1989, 26, 69-112. [CrossRef]

6. Lander, R.H.; Larese, R.E.; Bonnell, L.M. Toward more accurate quartz cement models: The importance of euhedral versus noneuhedral growth rates. Aapg Bull. 2008, 92, 1537-1563. [CrossRef]

7. Bukar, M. Does Oil Emplacement Stop Diagenesis and Quartz Cementation in Deeply Buried Sandstone Reservoirs; University of Liverpool: Liverpool, UK, 2013.

8. Van de Kamp, P.C. Smectite-illite-muscovite transformations, quartz dissolution, and Silica release in shales. Clays Clay Miner. 2008, 56, 66-81. [CrossRef]

9. Harwood, J.; Aplin, A.C.; Fialips, C.; Iliffe, J.E.; Kozdon, R.; Ushikubo, T.; Valley, J.W. Quartz cementation history of sandstones revealed by high-resolution SIMS oxygen isotope analysis. J. Sediment. Res. 2013, 83, 522-530. [CrossRef]

10. Oye, O.J.; Aplin, A.C.; Jones, S.J.; Gluyasa, J.G.; Bowenb, L.; Orlandc, I.J.; Valley, J.W. Vertical effective stress as a control on quartz cementation in sandstones. Mar. Pet. Geol. 2018, 98, 640-652. [CrossRef]

11. Walderhaug, O. Kinetic modeling of quartz cementation and porosity loss in deeply buried sandstone reservoirs. AAPG Bull. 1996, 80, 731-745.

12. Walderhaug, O. Modeling quartz cementation and porosity in Middle Jurassic Brent Group sandstones of the Kvitebjørn field, northern North Sea. AAPG Bull. 2000, 84, 1325-1339. [CrossRef]

13. Lander, R.H.; Walderhaug, O. Predicting porosity through simulating sandstone compaction and quartz cementation. AAPG Bull. 1999, 83, 433-449.

14. Hiatt, E.E.; Kurtis, T.K.; Fayek, M.; Polito, P.; Holk, G.J.; Riciputi, L.R. Early quartz cements and evolution of paleohydraulic properties of basal sandstones in three Paleoproterozoic continental basins: Evidence from in situ $\delta^{18} \mathrm{O}$ analysis of quartz cements. Chem. Geol. 2007, 238, 19-37. [CrossRef]

15. Hyodo, A.; Kozdon, R.; Pollington, A.D.; Valley, J.W. Evolution of quartz cementation and burial history of the Eau Claire Formation based on in situ oxygen isotope analysis of quartz overgrowths. Chem. Geol. 2014, 384, 168-180. [CrossRef]

16. Longstaffe, F.J.; Ayalon, A. Oxygen-Isotope Studies of Clastic Diagenesis in the Lower Cretaceous Viking Formation, Alberta: Implications for the Role of Meteoric Water; Geological Society, Special Publications: London, UK, 1987; Volume 36, pp. $277-296$.

17. Guo, Z.W.; Deng, K.L.; Han, Y.H. Formation and Evolution of the Sichuan Basin; Geological Publishing House: Beijing, China, 1996; pp. 1-200, (In Chinese with English Abstract).

18. Gao, B.; Tian, F.; Pan, R.; Zheng, W.H.; Li, R.; Huang, T.J.; Liu, Y.S. Hydrothermal Dolomite Paleokarst Reservoir Development in Wolonghe Gasfield, Sichuan Basin, Revealed by Seismic Characterization. Water 2020, 12, 579. [CrossRef]

19. Yue, D.L.; Wu, S.H.; Xu, Z.Y.; Xiong, L.; Chen, D.X.; Ji, Y.L. Reservoir quality, natural fractures, and gas productivity of upper Triassic Xujiahe tight gas sandstones in western Sichuan Basin, China. Mar. Pet. Geol. 2018, 89, 370-386. [CrossRef]

20. Ni, Y.Y.; Dai, J.X.; Tao, S.Z.; Wu, X.Q.; Liao, F.R.; Wu, W.; Zhang, D.J. Helium signatures of gases from the Sichuan Basin, China. Org. Geochem. 2014, 74, 33-43. [CrossRef] 
21. Lai, J.; Wang, G.W.; Ran, Y.; Zhou, Z.L. Predictive distribution of high-quality reservoirs of tight gas sandstones by linking diagenesis to depositional facies: Evidence from Xu-2 sandstones in the Penglai area of the central Sichuan basin, China. J. Nat. Gas Sci. Eng. 2015, 23, 97-111. [CrossRef]

22. Tao, S.Z.; Zou, C.N.; Mi, J.K.; Gao, X.H.; Yang, C.; Zhang, X.X.; Fan, J.W. Geochemical comparison between gas in fluid inclusions and gas produced from the Upper Triassic Xujiahe Formation, Sichuan Basin, SW China. Org. Geochem. 2014, 74, 59-65. [CrossRef]

23. Luo, L.; Meng, W.B.; Gluyas, J.; Tan, X.F.; Gao, X.Z.; Feng, M.S.; Kong, X.Y.; Shao, H.B. Diagenetic characteristics, evolution, controlling factors of diagenetic system and their impacts on reservoir quality in tight deltaic sandstones: Typical example from the Xujiahe Formation in Western Sichuan Foreland Basin, SW China. Mar. Pet. Geol. 2019, 103, 231-254. [CrossRef]

24. Zhang, S.L.; Lv, Z.X.; Wen, Y.; Liu, S.B. Origins and Geochemistry of Dolomites and Their Dissolution in the Middle Triassic Leikoupo Formation, Western Sichuan Basin, China. Minerals 2018, 8, 289. [CrossRef]

25. Zhang, L.; Guo, X.S.; Hao, F.; Zou, H.Y.; Li, P. Lithologic characteristics and diagenesis of the upper triassic Xujiahe Formation, yuanba area, northeastern Sichuan Basin. J. Nat. Gas Sci. Eng. 2016, 35, 1320-1335. [CrossRef]

26. Xu, C.M.; Gehenn, J.M.; Zhao, D.H.; Xie, G.Y.; Teng, M.K. The fluvial and lacustrine sedimentary systems and stratigraphic correlation in the Upper Triassic Xujiahe Formation in Sichuan Basin, China. AAPG Bull. 2015, 99, 2023-2041. [CrossRef]

27. Yuan, G.H.; Cao, Y.C.; Gluyas, J.; Cao, X.; Zhang, W.B. Petrography, fluid-inclusion, isotope, and trace-element constraints on the origin of quartz cementation and feldspar dissolution and the associated fluid evolution in arkosic sandstones. AAPG Bull. 2018, 102, 761-792. [CrossRef]

28. Li, X.H.; Li, Z.X.; He, B.; Li, W.X.; Li, Q.L.; Gao, Y.Y.; Wang, X.C. The Early Permian active continental margin and crustal growth of the Cathaysia Block: In situ U-Pb, Lu-Hf and O isotope analyses of detrital zircons. Chem. Geol. 2012, 328, 195-207. [CrossRef]

29. Clayton, R.N.; O’Neil, J.R.; Mayeda, T.K. Oxygen isotope exchange between quartz and water. J. Geophys. Res. 1972, 77, 3057-3067. [CrossRef]

30. Aplin, A.C.; Warren, E.A. Oxygen isotopic indications of the mechanisms of silica transport and quartz cementation in deeply buried sandstones. Geology 1994, 22, 847-850. [CrossRef]

31. Wilkinson, M.; Crowley, S.F.; Marshall, J.D. Model for the evolution of oxygen isotope ratios in the pore fluids of mudrocks during burial. Mar. Pet. Geol. 1992, 9, 98-105. [CrossRef]

32. Girard, J.P.; Munz, I.A.; Johansen, H.; Hill, S.; Canham, A. Conditions and timing of quartz cementation in Brent reservoirs, Hild Field, North Sea: Constraints from fluid inclusions and SIMS oxygen isotope microanalysis. Chem. Geol. 2001, 176, 73-92. [CrossRef]

33. Muttoni, G.; Mazza, M.; Mosher, D.; Katz, M.E.; Kent, D.V.; Balini, M. A Middle-Late Triassic (Ladinian-Rhaetian) carbon and oxygen isotope record from the Tethyan Ocean. Palaeogeogr. Palaeoclimatol. Palaeoecol. 2014, 399, 246-259. [CrossRef]

34. Korte, C.; Kozur, H.W.; Veizer, J. $\delta^{13} \mathrm{C}$ and $\delta^{18} \mathrm{O}$ values of Triassic brachiopods and carbonate rocks as proxies for coeval seawater and palaeotemperature. Palaeogeogr. Palaeoclimatol. Palaeoecol. 2005, 226, 287-306. [CrossRef]

35. Liu, S.B.; Huang, S.J.; Shen, Z.M.; Lv, Z.X.; Song, R.C. Diagenetic fluid evolution and water-rock interaction model of carbonate cements in sandstone: An example from the reservoir sandstone of the Fourth Member of the Xujiahe Formation of the XiaoquanFenggu area, Sichuan Province, China. Sci. China Earth Sci. 2014, 57, 1077-1092. [CrossRef] (In Chinese with English Abstract)

36. Hurst, A.; Irwin, H. Geological modelling of clay diagenesis in sandstones. Clay Miner. 1982, 17, 5-22. [CrossRef]

37. Franca, A.B.; Aranujo, L.M.; Maynard, J.B.; Potter, P.E. Secondary porosity formed by deep meteoric leaching: Botucatu eolianite, southern South America. AAPG Bull. 2003, 87, 1073-1082. [CrossRef]

38. Liu, Y.F.; Hu, W.X.; Cao, J.; Wang, X.L.; Tang, Q.S.; Wu, H.G.; Kang, X. Diagenetic constraints on the heterogeneity of tight sandstone reservoirs: A case study on the Upper Triassic Xujiahe Formation in the Sichuan Basin, southwest China. Mar. Pet. Geol. 2018, 92, 650-669. [CrossRef]

39. Sun, H.T.; Zhong, D.K.; Zhan, W.J. Reservoir characteristics in the Cretaceous volcanic rocks of Songliao Basin, China: A case of dynamics and evolution of the volcano-porosity and diagenesis. Energy Explor. Exploit. 2019, 37, 607-625. [CrossRef]

40. Leder, F.; Park, W. Porosity reduction in sandstone by quartz overgrowth. Aapg Bull. 1986, 70, 1713-1728.

41. Morad, S.; AlDahan, A.A. A SEM study of diagenetic kaolinitization and illitization of detrital feldspar in sandstones. Clay Miner. 1987, 22, 237-243. [CrossRef]

42. Zaid, S.M. Provenance, diagenesis, tectonic setting and geochemistry of Rudies sandstone (Lower Miocene), Warda Field, Gulf of Suez, Egypt. J. Afr. Earth Sci. 2012, 66-67, 56-71. [CrossRef]

43. Perry, E.A.; Hower, J. Burial diagenesis in Gulf Coast pelitic sediments. Clay Clay Miner. 1970, 18, 167-177. [CrossRef]

44. Lynch, F.L.; Mack, L.E.; Land, L.S. Burial diagenesis of illite/smectite in shales and the origins of authigenic quartz and secondary porosity in sandstones. Geochim. Cosmochim. Acta 1997, 61, 1995-2006. [CrossRef]

45. Chang, H.K.; Mackenzie, F.T.; Schoonmaker, J. Comparisons between the diagenesis of dioctahedral and trioctahedral smectite, Brazilian offshore basins. Clays Clay Miner. 1986, 34, 407-423. [CrossRef]

46. Oelkers, E.H.; Bjorkum, P.A.; Murphy, W.M. A petrographic and computational investigation of quartz cementation and porosity reduction in North Sea sandstones. Am. J. Sci. 1996, 296, 420-452. [CrossRef]

47. Walderhaug, O. Kaolin-Coating of Stylolites, Effect on Quartz Cementation and General Implications for Dissolution at Mineral Interfaces. J. Sediment. Res. 2006, 76, 234-243. [CrossRef] 